\title{
INFLUENCE OF INTEREST GROUPS IN LATVIA ON CENTRALIZATION Māris Pūḳis ${ }^{1}$, Lilita Seimuškāne ${ }^{2}$
}

\begin{abstract}
Latvia has experienced four administrative-territorial reforms in 30 years. In 1989, local and regional elections were the first democratic elections in Latvia since 1934. From 1990 to 1992, self-governments were the main authority for reestablishing national independence and transforming the country from totalitarianism to democracy. The transformation process starts with wide decentralization, including substantial fiscal decentralization and substantial administrative decentralization.

The first reform was the centralization (1994) of Rìga city government (1 self-government instead of a two-tier system, with 6 district local governments and 1 city local government). The second reform abolished elections in 26 regional councils (1998) and replaced them by delegates from local governments. The third reform (2009) was abolishing regional governments and reducing the number of local governments 5 times. The fourth reform will be implemented after June 52021 , and its content is reduction of the number of municipalities 3 times. Therefore, from 596 local and regional governments in 1990s, Latvia will only have 42 local governments.

All those reforms were directed towards centralization. Official goals of public administration reforms can differ from real intents of pressure groups, who impact ruling political parties and central government decisions. The paper aims to analyze reforms depending on pressure groups, who believe in benefits from centralization. Methods of policy analysis and grouping of statistics about administrative territories are used.

They provided research shows that real goals of all four reforms were an expression of political competition. Dominating interest groups in each case have conflicting interests. Previous reforms facilitated emigration and peripheries effect, while the positive impact on regional development is not achieved. The impact of the last reform will largely depend on the results of the next parliamentary election of 2022 .
\end{abstract}

UDC Classification Number: 351; 352; 353; 354; DOI: https://doi.org/10.12955/pss.v2.239

Keywords: local government, Administrative territorial reform, interest groups, centralization, Latvia

\section{Introduction}

Latvia has two specific features, which differ from a majority of Central and Eastern European countries.

Before the restoration of national independence in 1990, a large-scale decentralization was conducted. Latvia gained municipal freedoms before democratization on the national scale. In 1990, selfgovernments' (local and regional) expenditures were $54 \%$ of the total public budget. Local government elected deputies meeting of April 21 of 1990 by more than 8000 votes decided, that the national parliament in its first meeting day must declare independence. After 55 years of totalitarianism, local councilors were dominating power of the Popular Front of Latvia (Pūķis, 2010).

Relatively soon, in December of 1991, a local and regional governments association was established, which in three years achieved voluntary membership close to $100 \%$ and established a formal and informal consultation system with the central government and parliament.

After the restoration of national independence in 1990, Latvia has experienced four administrativeterritorial reforms:

a) Centralization of Rīga city government (1994), when instead of two-scale governments in the capital city (Rīga +6 districts), only one - government of the capital city - was established;

b) Abolishing of direct elections (1998) for the regional governments;

c) Centralization of the first scale - local governments, with abolishing of the second scale regional governments (2009) by reducing the number of self-governments 5 times;

d) Centralization of local governments (2021) by reducing the number of self-governments 3 times.

Official goals of all 4 reforms are related to the belief in the economy of scale. The aim of this paper is to evaluate beneficiaries and losers, whose pressure on ruling political parties was significant. Local and regional reforms are compared with the content of public administration reform stages (Pukis et al., 2017).

\section{Stages of Public Administration Reforms}

Directions of public administration reforms are external factors with substantial influence on local governments, particularly on administrative-territorial reforms. One more stage to the classification of

\footnotetext{
${ }^{1}$ University of Latvia, Faculty of Business, Management and Economics, maris.pukis@lu.lv

${ }^{2}$ University of Latvia, Faculty of Business, Management and Economics, lilita.seimuskane@lu.lv
} 
public administration reforms stages, which depend on prevailing interest groups (Pukis et al., 2017), needs to be added by the present period.

Transitional (1990-1993)

The dominating beneficiary were people of Latvia. At this stage, there was a competition between the Popular Front of Latvia and supporters of staying in the zone of Russian dominance. The prevailing ideology was nationalism and anti-communism. Public administration reform led to de-occupation from Russian troops, democratization, and decentralization.

Elements of minimal governance were topical, and they were used to change bureaucrats of Soviet times partially. An approach of minimal central government allowed fiscal and administrative decentralization. Transition was performed by active participance of local and regional governments, which was the main reason for establishing a formal and informal consultation system between the central power (government and parliament) and self-governments (represented by single association LALRG). The system also included consultations with smaller interest groups and specific local governments.

Pseudo-restoration (1993-1998)

Dominating beneficiaries were privatizers. At this stage, there was a competition among new political parties, which expressed the interests of different groups for privatization. Prevailing ideologies were liberalism and nationalism. The competition was among different interest groups, representing old soviet nomenclature and those who come from anti-communists and were willing to become capitalists faster. The period was characterized by the creation of the national political elite. In the interests of privatization, a sophisticated and non-transparent legislative environment allowed hiding beneficiaries during the privatization process. The Civil service, instead of employees under labor law, was introduced. An intent of the new elite was to make the civil service is a tool for the implementation of their interests. For this purpose, a mandarin model for the organization of bureaucracy was selected. "

Max Weber type administration was topical. That led to a shift from minimal government to a gradual over-regulation. Newly arising bureaucracy tried to subtract power from the self-governments that were provided to them during the previous period. Self-governments were put under increasing pressure of regulations issued by the Cabinet of Ministers. There were attempts to minimize personal autonomy by the inclusion of local governments' employees in the state civil service. That was prevented by a strong position of LALRG.

New Public Management (1998-2002)

Dominating beneficiaries were the new political elite and foreign investors. At this stage, property rights were stabilized. Those, who were successful during the previous periods, needed to protect their property and assets. The privatized assets had to be sold, and the acquired assets had to be disposed of in offshores.

Providers of interests of foreign investors gradually became more significant. Germany and France were interested in the preparedness of Latvia to join NATO and EU. Russia was concerned about the destabilization of the social and economic situation. There were changes in the political elite, which led to a necessity to renew civil servants. An idea about the transformation from Weberian administrative system to New public management was suitable.

Several elements of the new administrative approach were used against local and regional democracy. Division of executive power from legislative power was applied to introduce executive directors to decrease the authority of local councils. Introduction of Quality Management helped bureaucratization and over-regulation, and primary and secondary legislation decreased the level of freedom for local and regional policy.

At the end of this period, the central government decided (as of 2002) on Latvia as a single EU statistical region under NUTS 2. This decision meant centralized management of EU funds according to a common development plan and concentration of $6 \mathrm{EU}$ funds administration in the hands of the Ministry of Finance. That was a shift to facilitating emigration from rural territories and the concentration of resources in and around Riga.

Joining NATO and EU (2002-2008)

Content of that period: achievement conditions for national security. Membership in NATO and EU provided Latvia with a basis for peace and development, and that is in the interests of the entire country. 
At the same time, hurrying to both organizations forced Latvian politicians to make many mistakes. The country missed an opportunity to strengthen public infrastructure, trying to fulfill the financial requirements of joining the EU. The country also missed an opportunity to have its own investment program, putting all efforts in proper use of the EU multilevel budget. Latvia launched an austerity policy many years before the global economic crisis of 2008, and that led to an underdeveloped and weakly protected internal market.

Dominating beneficiaries of that period were investors in the banking sector and real estate. Namely, their interests were a reason for the administrative-territorial reform at the end of the period.

In the public administration policy, there was a shift away from New Public management. Neo Weberism was topical abroad, and the national elite used it for changing civil servants and higher officials in sectoral ministries.

Populism came into the political agenda during the middle of the period. It was hidden under an anticorruption policy. The red type was increasing. It was hidden under strengthening the rule of law.

\section{Internal devaluation (2008-2018)}

Internal devaluation was a policy of the Latvian central government to fight the global economic crisis. A series of wrong decisions started with an unnecessary fight against inflation and, afterward, cutting down the internal market. The result was returning to the level of 2007 for GDP in comparative prices only in 2018.

Dominating interest groups of that period were international finance organizations and foreign banks, who put pressure to develop a mandatory funded pension system and withdraw the capital from Latvia, providers of foreign investments, and political parties trying to increase their trust by fighting selfgovernments. Local governments helped the central government solve problems of the crisis and tried to protect local democracy and kept opportunities for the regional development of the country.

This period is characterized by the intents of privatization of state and local government enterprises, which remained in public ownership after 1990's. That was the opposite to values of the New public management period when the efficiency of public agencies and public enterprises were among the goals of the local and national government. During that period, the state lost its last bank, and loaning policy became fully dependent on foreign banks' subsidiaries. Pressure to privatize state assets in forestry, railway, energetics, and telecommunications was very high.

For local governments, a loss of several achievements of previous periods was a characteristic of the period: the flexible and fully autonomous remuneration system was changed by including local governments in a single system for the public sector, and finance equalization was made less beneficiary for development of welfare in the territory. At the end of the period, workforce taxes were redistributed by decreasing the share of local budgets.

Populism (2018-present)

The parliamentary election of 2018 led to a win of three new political parties, whose programs were based on negativism - on a promise of finding guilty persons and punishing them. That was an expression of voters' dissatisfaction with slow returning to progress and weak social policy. Thus, a coalition government with 5 members was created under the leadership of an "old" party with the smallest representation in the parliament. The party of the Prime Minister has only 8 of 100 positions.

Ideologies and programs of ruling coalition members are very different. In Declaration of the Intended Activities of the Cabinet of Ministers (2018), they included a number of positive promises, which led to quarrels among the coalition members or were unrealistic. Only one of the intents can be joining - an idea about decreasing the number of local governments. In the political agenda, a fight against COVID19 relieved the situation of positive promises of the administrative-territorial reform.

Dominating interest groups of that period with the influence of national policy are external. The majority of privatization goals of the previous period were not achieved. Currently, the banking system of Latvia is substantially weakened by an excessive fight against money laundering. Economic activities in Russia are minimized by trying to punish Russia for its aggression against Ukraine.

Public administration reforms tend to destroy representative democracy and decrease the impact of elected members of the parliament and elected local councilors on executive power. Increasing 
participative democracy by weakening political parties and weakening local governments is hidden under the wording of "good governance"

\section{Centralization}

There are several forms of political centralization from local government. All forms of centralization assume the enlargement of the distance between the citizens and power.

First form - to transform competences from local governments to the national government (or any other "highest level"), without a change in scale.

Second form - to enlarge territory of local governments by merging several territorial units; merging local communities takes away the self-governance of smaller communities.

Third form - to issue national or regional regulations regarding competences of local governments.

All three forms decrease the impact of the local community on local affairs and take away competence from the local community. The principle of subsidiarity allows performing centralization, but only provided that the local government needs support from higher authorities (Pius XI, 1931, par. 79 and 80). European Charter of Local Self-Government (Council of Europe, 1985, Art. 4.3), hereinafter referred to as the Charter, allows centralization only up the extent and nature of the task and requirements of efficiency and economy. In the judicial area of the EU, an important element for the implementation of subsidiarity is Protocol No. 2 to the Treaty of European Union (EU, 2012). Authority, who propose centralization in any form, is obliged to prove that action or legal norm corresponds to the principle of subsidiarity.

\section{$1^{\text {st }}$ reform - Centralization of Rīga city (1994)}

During the first years after the self-government election of 1989, city government in Rīga co-existed with 6 district governments. The legislative basis for the city and districts was the same - law on city government. Competences between the city and districts were redistributed based on traditions and mutual agreements.

Districts were among the founders of the LALRG in December of 1991. Riga joined the LALRG only in 1994, after the centralization of the city. District governments were actively involved in all activities of the transition period: democratization, decentralization, privatization of land, restitution of property rights, de-occupation from Russian troops.

There was a competition between the two co-existing two scales of city government regarding the performance of those functions. For example: two of the districts considered the territory of Rìga port to be their property, city tried to exclude the port from municipal ownership of districts. There were different opinions about responsibility on privatization of public services, being in that time municipal property.

District governments and city governments have different opinions about the perspective of division and structure of competences. District governments prepared a draft law on self-government structure in Rìga, while central government prepared another draft law (from 1990 to 1994, it was possible for local councils to propose draft laws directly to the Parliament and participate in discussions by taking part in plenary sessions).

Such opportunity - to participate in a debate before the Parliament votes on the draft law proposed by local government - is not known in present western democracies and characterizes the level of decentralization of that period. Both proposals were rejected, and a compromise version was adopted (Supreme Council, 1992) - Law on Capital City Rīga Self-Government, which was in force from June 1992 to June 1994.

The official reason for the reform was intent of unification, and belief that all residents of Riga city needed equal rights and equal opportunities. Only 4 years after returning from the totalitarian regime to pluralism and diversity, the idea of equality was again on the political agenda.

The idea about Rigga city centralization was proposed to the LALRG in its $2^{\text {nd }}$ Congress in January 1993 (Pūkisis, 2010). Local governments rejected the proposal on the elimination of regional governments, while local governments allowed centralization of Rīga city. At that moment, local politicians failed to understand that centralisation of Rigga city is only the first step in alienating citizens from the local government. 
The main interest groups, beneficiaries, and losers after the centralization of Rìga city are shown in Table 1. The beneficiaries are the political elite, which supported privatizers of transit business and enterprises, the majority of which had their legal address in Rīga.

\begin{tabular}{|c|c|c|}
\hline Reform & Dominating interest groups & Interests \\
\hline \multirow{5}{*}{$\begin{array}{l}\text { Rīga city } \\
\text { centralization } \\
1994\end{array}$} & \multirow[t]{3}{*}{ New political elite } & $\begin{array}{l}\text { Privatization of largest enterprises and transit } \\
\text { infrastructure in Rīga city }\end{array}$ \\
\hline & & $\begin{array}{l}\text { Restoration of influence on the national } \\
\text { government by centralization }\end{array}$ \\
\hline & & To obtain control over the Rīga port \\
\hline & $\begin{array}{l}\text { Bureaucracy, thinking in the categories } \\
\text { of a totalitarian regime }\end{array}$ & $\begin{array}{l}\text { Establishment of a common normative and } \\
\text { common order for all districts of Rīga }\end{array}$ \\
\hline & $\begin{array}{l}\text { Residents of } 3 \text { districts and } 3 \text { suburbs ( } 3 \\
\text { districts were renamed as suburbs) }\end{array}$ & $\begin{array}{l}\text { Keeping of an opportunity to elect local } \\
\text { governments with autonomous budgets and } \\
\text { interest in the development of districts and } \\
\text { suburbs }\end{array}$ \\
\hline
\end{tabular}

City residents and small entrepreneurs were not ready to protect their interests. Propaganda for 55 years increased the number of believers that large organizations are better than small ones.

Two levels of government in Rīga city could facilitate competition among larger (6 larger cities in regions) cities and 6 Rīga districts, which were comparable by size. That could lead to more polycentric development, more active role, and a greater impact of self-governments on Latvia development. Decision on centralization led to monocentric model - Rìga metropolitan region concentrates a majority of country resources; regional disparities were permanently increasing.

The political consequence from Rìga city centralization was a permanent difference between ruling parliamentary coalition and the ruling Rịga city coalition. Polycentric city development could soften that contradiction with positive effect.

$2^{\text {nd }}$ reform - Elimination of direct elections for regional governments (1997-1998)

From 1991 to 1992, the system of "executive committees" was abolished. Ministries were not commanders for regional authorities, and regional governments were not commanders for local governments. The institutional hierarchy of any form was abolished. That was achieved by the separation of competences. Central ministries lose control. New legislation was minimal, and the level of freedom for local decision-makers was high.

Regional governments were responsible for primary and secondary healthcare, including financing and regulation. From 1993 to 1996, three substantially different health care administration systems were tested: capitation system, points system, and office system. Each of 26 regional governments has an autonomous health care organization policy. That allows comparing them and learning from them.

The new political elite needed to return to hierarchy. Regional governments were the next victim after decentralized Rīga city.

The fight of the central government against regional (district) governments started soon after the reestablishment of political parties' system:

- 1993 - proposal to eliminate self-governments at the regional level and introduce regional agencies of central government (this proposal was rejected on the $2^{\text {nd }}$ Congress of the LALRG).

- 1995 - taking away own revenues (a share of district governments from individual income tax); instead, the regional governments were further financed by a grant from equalization fund).

- 1994 - 1997 facilitating process of delegation of regional competences to local governments of district centers.

- 1997 - reform for centralization of financing and organization of the primary and secondary health care.

- 1997 - elimination of direct elections.

After the systematic weakening of the regional level, there was an agreement with the LALRG about preserving indirectly elected councils (consisting of mayors from local governments) at the respective regional level. 
There were beneficiaries and losers (Table 2) - the main beneficiaries from the reform - political parties of the ruling coalition, fighting their internal opponents. The mayors were from Latvian Farmers' party in most regional governments, the smallest member of many coalitions. The largest members of the ruling coalition mutually fight about electors of that party.

Beneficiaries are doctors of tertiary care hospitals in Riga city. They achieved concentration of health care mainly in 4 hospitals from 140 (100 of them were under local and regional governments ownership). Sponsors of political parties with privatization interests or state aid interests needed a sectoral approach to economics, and they disagree on disseminating government activities to regions.

Residents of regions were the losers since the sectoral approach led to emigration and to decreasing economic activity outside the metropolitan area of Rìga.

Table 2: Dominating interest groups of the second Administrative Territorial reform in Latvia in 19971998

\begin{tabular}{|l|l|l|}
\hline \multicolumn{1}{|c|}{ Reform } & \multicolumn{1}{|c|}{ Dominating interest groups } & \multicolumn{1}{c|}{ Interests } \\
\hline $\begin{array}{l}\text { Elimination of } \\
\text { representative } \\
\text { democracy for } \\
\text { regional } \\
\text { governments } \\
1997,1998\end{array}$ & Doctors from tertiary care hospitals & $\begin{array}{l}\text { Centralization of primary and secondary } \\
\text { health care }\end{array}$ \\
\cline { 2 - 3 } & Sponsors of ruling parties & $\begin{array}{l}\text { Strengthening of sectoral approach, } \\
\text { prevention of regionalization before joining } \\
\text { EU }\end{array}$ \\
\cline { 2 - 3 } & Central bureaucrats & $\begin{array}{l}\text { Development of normativism to decrease the } \\
\text { impact of local government decisions }\end{array}$ \\
\cline { 2 - 3 } & Local governments of district centres & $\begin{array}{l}\text { Larger competence and property of city } \\
\text { governments by decreasing impact of district } \\
\text { governments }\end{array}$ \\
\cline { 2 - 3 } & Local governments & $\begin{array}{l}\text { Preservation of the regional approach of } \\
\text { development policy }\end{array}$ \\
\cline { 2 - 3 } & $\begin{array}{l}\text { The population of regions outside the } \\
\text { metropolitan area of Riga }\end{array}$ \\
\hline Source: Authors & \multicolumn{2}{|l}{} \\
\hline
\end{tabular}

The flag of this reform again was an idea of unification and equal rights of the population in regions to receive better services.

$3^{\text {rd }}$ reform - Creation of amalgamated municipalities (novads) (2009)

In parallel to an agreement about indirectly elected regional governments, the Parliament accepted Administrative - Territorial Reform Law (Saeima, 1998). The initial version includes several principles, which are not implemented until the present:

- A chapter about the regional reform, including decentralization of central government functions to directly elected regional governments ("apriņ̧̧a pašvaldība") by application of the principle of subsidiarity.

- Voluntary amalgamation and choice of local governments to amalgamate or establishment of effective cooperation.

During this period, a compulsory administrative-territorial reform was intensely being prepared. The government was gradually refusing previously adopted principles of the reform:

- In 2003, cooperation is seen as a form of the local reforms was ceased (the cooperation methods widely employed in France and Germany would not be allowed in Latvia).

- In 2005, a section about establishing regional self-governments was excluded from the law. The requirement of the subsidiarity principle was also excluded.

- During the reform, all local governments were visited numerous times, and several merger scenarios were discussed by granting a state block grant to each local government that voluntarily merged. To achieve this goal, a total of about 150 million euros was spent.

The reaction of the society to the reform remained negative. In all the surveys performed in the period 1999-2009, most of the respondents were against.

The process of voluntary amalgamation was supported only by a part of the local governments. First amalgamation, which was created around Kandava municipality, happened voluntarily and before it was defined in law. Until the introduction of the compulsory stage, more than 40 amalgamated municipalities ("novada pašvaldība") were voluntarily established. 
During the reform, the total amount of self-governments was decreased 5 times, and the regional level was eliminated. Property and functions of regional governments were transformed to the local level.

The time of the reform matched the time of the global economic crisis. And it was not a coincidence! Paradox is, that the real main reason for the reform was also one of the main reasons for the world crisis. Before that, there were very active speculations with real estate. Namely interests of those speculators and impact of that interest group were dominating in the $3^{\text {rd }}$ reform and increasing the prices of lands and buildings before the crisis was very fast. Such increasing largely depends on spatial planning, which is one of the main competences of local municipalities.

Before the reform, political parties had a small influence on local governments (Table 3). From 504 municipalities of small cities and towns, political parties won the majority of places only in 56 municipalities, and 16 of them were centers of the district, 19 - towns (centre of district), and $37-$ rural municipalities ("pagasts").

Table 3: Number of municipalities, where political parties in the municipal election won more than a half of mandates during $2005-2008$

\begin{tabular}{|l|c|c|c|}
\hline \multicolumn{1}{|c|}{ NUTS3 region } & $\begin{array}{c}\text { Number of } \\
\text { districts }\end{array}$ & $\begin{array}{c}\text { Number of local } \\
\text { governments }\end{array}$ & $\begin{array}{c}\text { Number of municipalities where } \\
\text { political parties get more than 50\% } \\
\text { places (6 cities are not included) }\end{array}$ \\
\hline Zemgale region & 5 & 94 & 16 \\
\hline Vidzeme region & 5 & 103 & 7 \\
\hline Latgale region & 6 & 132 & 12 \\
\hline Kurzeme region & 5 & 78 & 23 \\
\hline Pierīga region & 5 & 97 & 56 \\
\hline \multicolumn{1}{r|}{ Total } & 26 & 504 & 23 \\
\hline
\end{tabular}

Source: Summary made by the authors using data of the Central Election Commission of Latvia

Riga and 6 larger cities have competences of regional and local governments. If the number of residents exceeds 5000, only political parties can participate in the race. In other cases, candidate list can be proposed by a pre-election association of voters. In rural municipalities, political parties are not popular. Electors vote for local interests and local lists. Therefore, political parties have influence only on $56+$ $7=63$ municipalities from 511 .

Those 63 municipalities have more than $80 \%$ of residents, but they represent a small part of the territory. Supporters of political parties cannot influence the allowed usage of land. This was the actual reason, why ruling parties decided to eliminate regional governments and to decrease the number of municipalities to 119. Until 2007, central governments spoke about amalgamation reform many times, but such a maneuver was mainly used to divert attention from privatization events (Pūķis, 2010). The position was changed when important economic interest was raised (Table 4).

Table 4: Dominating interest groups of the third Administrative Territorial reform in Latvia in 2009

\begin{tabular}{|l|l|l|}
\hline \multicolumn{1}{|c|}{ Reform } & \multicolumn{1}{c|}{ Dominating interest groups } & \multicolumn{1}{c|}{ Interests } \\
\hline $\begin{array}{l}\text { Amalgamation of } \\
\text { local governments } \\
\text { and abolishment of } \\
\text { regional } \\
\text { governments } 2009\end{array}$ & Real estate investors & $\begin{array}{l}\text { To lobby interests in land use regulation in } \\
\text { offices of central political parties }\end{array}$ \\
\cline { 2 - 3 } & Political parties & $\begin{array}{l}\text { To decrease the influence of residents on the } \\
\text { results of local elections }\end{array}$ \\
\cline { 2 - 3 } & Large farmers & $\begin{array}{l}\text { To prevent creating of strong, democratically } \\
\text { elected regional governments }\end{array}$ \\
\cline { 2 - 3 } & $\begin{array}{l}\text { Residents of civil parishes and } \\
\text { smallest towns }\end{array}$ & $\begin{array}{l}\text { To facilitate emigration from rural territories } \\
\text { development of their territory }\end{array}$ \\
\cline { 2 - 3 } & & Get basic services close to residents \\
\hline
\end{tabular}

Source: Authors

Elimination of district (regional) governments looked like a victory of central bureaucracy. Ministries fought for public resources and saw the regions as competitors. Elimination of regional authorities led to a weakening of the subnational sector. The victory is not full - each of the next reform laws delegates the Cabinet of Ministers to prepare a draft law on regions. And always (also presently), legal nihilism prevails, and political parties cannot agree on regions. 


\section{$4^{\text {th }}$ reform - Amalgamation around development centres (2021)}

An intent to ensure control of ruling political parties over the situation in local and regional governments by reform of 2009 was not achieved. Instead of the complete elimination of regional governments, planning regions remain. They are organized from down to up - development councils (highest decision makers) consisting only of the mayors of local councils (Pukis, 2017). Finances and opportunities of those imperfect regional governments are smaller than those of districts, eliminated by the previous reform; however, they have all the main attributes of self-government, except direct elections.

$1 / 3$ of municipalities ("novads") after elections of 2017 has their mayor, elected from a local list (all cases, when electoral proposal of candidate lists was allowed by the census of less than 5000 residents). Many other municipalities were controlled by local political parties. Members of those parties were mainly from one or several municipalities, and the trust of residents in them was much higher than trust in national political parties. Programs of those parties were tended to local needs of citizens and critics of the regional development policy of the ruling coalition.

The novelty of the period before the parliamentary election of 2018 (Pukis et al., 2017) has been the aspirations of the central governments to split the local governments by opposing the interests of different local governments and acquiring some political dividends at the following local or Saeima elections.

On the grounds of such conduct, the concept of development centres has been employed. In the national planning documents, the local governments have been divided in several groups. Nine republic cities have been presented with the higher status, thereby creating certain advantages for these governments as for receipt of the state investments (from the EU funds, in fact). Twenty-one municipalities with the regional development center (previous city as a center of post-reform municipality) have been presented with the intermediate status, and these local governments were presented with local development centres.

The parliamentary election of 2018 led to a change in the political elite. Three of five ruling coalition parties manifested victory of "new political forces". The political party of the previous Prime Minister stayed in opposition. All 5 coalition parties had small representation in local governments, and before the next parliamentary election of 2022, they needed administrative resources.

Overture for the reform was dismissing of Rìga city government, which was 10 of 25 years led by parliamentary opposition. The Congress of Local and Regional Authorities of the Council of Europe (CoE, 2020) was concerned about methods of suspending the mayor of Riga City from duty and afterward - about the dismissal of the city council.

\begin{tabular}{|l|l|l|}
\hline \multicolumn{3}{|c|}{ Table 5: Dominating interest groups of the fourth Administrative Territorial reform in Latvia in 2021} \\
\hline \multicolumn{1}{|c|}{ Reform } & \multicolumn{1}{|c|}{ Dominating interest groups } & \multicolumn{1}{c|}{ Interests } \\
\hline $\begin{array}{l}\text { Amalgamation } \\
\text { of local } \\
\text { governments } \\
\text { around } \\
\text { politically } \\
\text { defined centres }\end{array}$ & $\begin{array}{l}\text { "New political forces" (3 parties in } \\
\text { the 5 parties ruling coalition after } \\
\text { the parliamentary election of 2018) }\end{array}$ & $\begin{array}{l}\text { To obtain administrative resources for the } \\
\text { parliamentary election of 2022 by winning the } \\
\text { election of local governments in 2021 }\end{array}$ \\
\cline { 2 - 3 } & Political parties & $\begin{array}{l}\text { Abolish opportunity to elect local government } \\
\text { councilors from lists proposed by electors }\end{array}$ \\
\cline { 2 - 3 } & $\begin{array}{l}\text { To prevent creating of strong, democratically } \\
\text { elected regional governments }\end{array}$ \\
\cline { 2 - 3 } & $\begin{array}{l}\text { Local politicians from politically } \\
\text { determined "development centers" }\end{array}$ & $\begin{array}{l}\text { To concentrate resources in the center after the } \\
\text { amalgamation of territories, greater influence in } \\
\text { national scale }\end{array}$ \\
\cline { 2 - 3 } & Students of secondary schools & $\begin{array}{l}\text { To preserve the opportunity to learn close to } \\
\text { their place of residence }\end{array}$ \\
\cline { 2 - 3 } & $\begin{array}{l}\text { Persons employed near their place } \\
\text { of residence }\end{array}$ & To preserve the availability of job \\
\hline Source: Authors & \multicolumn{2}{|l}{} \\
\hline
\end{tabular}

During the reform, the central government found a reason to nationalize Rìga city port. To take away property rights of ports from city governments was a dream of central bureaucrats and political parties from the middle of 90-ies. The fight about Rìga port was among the reasons for the first administrativeterritorial reform. In the middle of 90-ies, ports became municipal property. In those years, transit business looked very prospective. Until 1994, ports' administrations were municipal institutions, 
determined by local councils and, starting from the middle of 1994 - mixed administrations determined by city council according to the law (also including central government representatives). From 2021, ports' administration functions are taken by state-owned enterprises (Saeima, 1994). That means readiness for further privatization. The case of ports is an example of how and why the central government performs territorial reforms (Table 5).

New political forces represented interest groups, which were concerned with the impact on economics. From June 5 2021, councilors in the 42 municipalities will only be representatives from political parties.

Each administrative-territorial reform is based on splitting. Among amalgamated municipalities, there are winners and losers. Typically, winners are new administrative centers. They hope to concentrate future revenues in the center. Losers are the municipalities, which after the amalgamation lose their influence on budget and become peripheries. The Ministry, implementing the reform, always try to get supporters from potential winners.

In the center of discussion about the last reform, there was a fulfilment of Article 5 of the Charter (Council, 1985). Several municipalities that were amalgamated during the reform can be regarded as sustainable (being donors of equalization system, increasing population, high incomes of residents and increasing entrepreneurship, an increasing number of students in secondary school). One of the sustainable municipalities, Ikšksile, organized a pool close to consultative referendum. Representativeness was the same as in the previous municipal elections. More than $98 \%$ of voters were against amalgamation. Ministry and parliament neglected the result (Ministry of Environmental Protection and the Regional Development Republic of Latvia, 2019). The Constitutional Court of the Republic of Latvia (2021) found that Article 5 of the Charter was not breached.

The attention of central authorities proves that the reform has other goals than the improvement of economics or social life. And in this case, political parties are the beneficiaries.

\section{Conclusions}

- In 30 years, Latvia has had 4 administrative territorial reforms, which were performed towards centralization.

- The substantial factor for all reforms - the impact of interest groups, which implement reforms by influencing political parties and civil servants.

- Method of splitting involved dominating groups into beneficiaries and losers could be used for explaining the difference between official goals and real intents of reform participants.

- Local government reforms are a part of public administration reforms, dominating interest groups that are closely connected.

\section{References}

Augstākā Padome [Supreme Council]. (1992) Likums "Par galvaspilsētas Rīgas pašvaldību" [Law on Capital City Rīga Selfgovernment]. Retrieved from: https://likumi.lv/ta/id/65317/redakcijas-datums/1994/01/10

Cabinet of Ministers. (2018) Declaration of the Intended Activities of the Cabinet of Ministers headed by Arturs Krišjānis Kariņš. Retrieved from: https://www.mk.gov.lv/en/media/1089/download

Central Election Commission of Latvia. https://www.cvk.lv/lv/velesanas/pasvaldibu-velesanas [Accessed 29.03.2021]

Constitutional Court of the Republic of Latvia. (2021) On Compliance of Sub-para 35.4. of "Annex to the Law on Administrative Territories and Populated Areas "Administrative Territories, Administrative Centres thereof and the Units of Territorial Division"' "with Article 1, the First Part of Article 101 of the Satversme and the Sixth Part of Article 4 and Article 5 of the European Charter of Local Self-Government.

Council of Europe. (1985, October 15) European Charter of Local Self Government. Treaty Nr.122.

Council of Europe. (2020) Fact-finding report on territorial reform in Latvia. Retrieved from: https://search.coe.int/cm/pages/result_details.aspx?ObjectId=0900001680a05b6f

European Union. (2012) Treaty of European Union. 2 Protocol On the application of the principles of subsidiarity and proportionality. Official Journal of the European Union. C 310/207, 16.12.2004

Pius XI. (1931) Quadragesimo Anno (May 15, 1931), http://www. vatican.va/content/pius-

xi/ne/encyclicals/documents/hf_p_xi_enc19310515_quadragesimo-anno.html [Accessed: 12.04.2021.]

Pūḳis, M. (2010) Pašu valdība - Latvijas pašvaldību pieredze, idejas un nākotnes redzējums. [Own Government - Latvian self-governments'experience, ideas and opportunities] Latvijas Pašvaldību savienība, pp.512, ISBN 978-9984-39-863-1

Pukis, M. (2017) Regionalization in Latvia: narrow range of competencies, but space for change. In: Report on the State of Regionalization. Assembly of European Regions. Retrieved from: https://aer.eu/regionalisation-latvia-narrow-rangecompetencies-space-change/ 
Pūḳis, M., Vorončuka, I., Stariṇeca, O. (2017) Public Administration Reforms in Latvia (1990-2016). In: Public Administration Reforms in Eastern European Union Member States - Post Accession Dimensions of Public Governance Convergence and Divergence (ed. Kovač, Bileišis). University of Ljubljana, Mykolas Romeris University, pp.90-138

Saeima [The Parliament of Latvia]. (1998) Administrative -Territorial Reform Law. Retrieved from: https://likumi.lv/ta/id/51528-administrativi-teritorialas-reformas-likums

Saeima. (1994) Law of Ports. Retrieved from: https://likumi.lv/ta/en/en/id/57435-law-on-ports

Ministry of Environmental Protection and Regional Development Republic of Latvia. (2019, April) Pašvaldību rīkotās aptaujas par reformu neatbilst likumam [Self- government polls on reform do not comply with the law]. Retrieved from: https://www.varam.gov.lv/lv/jaunums/varam-pasvaldibu-rikotas-aptaujas-par-reformu-neatbilst-likumam 